\title{
A Study on Awareness of Investment in Tax Saving Products
}

\author{
Varsha Singhania
}

Student

Rishi UBR PG College for Women

\begin{abstract}
Tax saving is an important concept as it helps in gaining deductions available from $80 \mathrm{C}$ and other deductions. This research study helps in identifying how one can gain benefits of Indian tax systems by utilizing various investment options mentioned under $80 \mathrm{C}$ of IT Act, 1961. This section provides up to Rs. 1,50,000 deductions. These investments include PPF, NSS, NPS, and ELSS etc. The major objective of the study was to know the respondents awareness on the Tax planning and Tax deductions, the source of awareness and the reason for preference of Investment. Tax planning helps in the reduction of tax amount and helps in utilizing the various reliefs, deductions, exemptions and rebates as per the IT Act, 1961. This research aims at knowing the most preferred tax saving instrument and the reason for its selection based on the mentioned criteria. Overall findings of the study reveal that $80 \mathrm{C}$ deductions is the most preferred one.
\end{abstract}

Keywords: Investment, Tax Saving Products, Income Tax Deductions

\section{Introduction}

\section{Tax Saving Investments}

Individual Taxpayers pay direct as well as Indirect Taxes. If an individual aims to reduce the Tax liability they can opt for Tax saving Instruments and can utilize the deductions as per Income Tax Act, 1961.

A person whose income is above a certain limit has to file an Income Tax return for Fiscal year. There are various Investment options that help in the reduction of Tax liability of an individual and can be referred to as "Tax Saving Products" or "Tax Saving Instruments".

\section{Objectives of the Study}

- To know the respondents awareness on the Tax planning and Tax deductions.

- To know the sources of Awareness about the Investment in Tax Saving Products to the respondents.

- To know the preference of Tax Saving Investments options of the respondents and to know the preference of respondents on the basis of Lock-down period of Investment, Returns and Taxability.

\section{Literature Review}

Bindabel and Hamza, (2021) state that the main objective of the study was to find out the relationship between saving and investment pattern and orientation towards finance among the working women at the universities of Saudi Arabia. Orientation towards finance (ORTOFIN) is one's attitude towards effectively managing financial activities.

Neha Agarwal, (2020) state that tax planning is an essential part of our financial planning. The main purpose of the study is to find out regarding the awareness and alternatives of the tax planning.

Arora \& Garg, (2019) in this research is an attempt to know the awareness and perception regarding 
various tax saving instruments available to save the tax to the teachers of higher education. The teachers are well aware of the various deductions, reliefs, and rebates available as per the Indian income tax act. They prefer those options of investment which are having low risk, high returns, and full tax benefits.

Arora \& Monika (Research Scholar, 2019) research paper is related with sensitive and personal financial aspects of individual income tax assesses. the researcher to undertake an empirical research on the topic to identify the factors that influence the individual assesses to invest in tax-saving schemes and scope for further investment. Depending upon their risk appetite, an increase has been witnessed in number of investment avenues available for investors.

Arora \& Rathi, (2018) studied the salaried employees' awareness and perception regarding various tax saving options. The study used correlation analysis and found a significant difference between the saving and investment patterns of men and women. Further, risk, return, and saving of tax were found to be the most important factors for investment decisions. The study also concluded that the medical deduction is underutilized and the tax rate should be reduced for salaried class.

\section{Research Methodology}

The present paper "A Study on Awareness of Investment in Tax Saving Products" is based on primary as well as secondary data. For primary data a survey was collected for 150 people and secondary data was collected from various research articles on related topics. The nature of the study was descriptive, sample size was 150 and data was collected through Questionnaire. The convenient random sampling method was used for data design and weighted average and Percentage Analysis were the statistical tools used.

\section{Limitations}

- It was difficult to obtain the data as the people who file Income Tax Returns were unwilling to give the information.

- It was difficult for some of the people to fill the deductions they were eligible for as they get the returns filed by Chartered Accountants and others.

- This study is done with reference to respondents who get their Income Tax File Returns by Agarwal Ankush \& Associates, with the sample size of 150 and therefore dependability of the project is not certain.

\section{Data Analysis \\ Age}

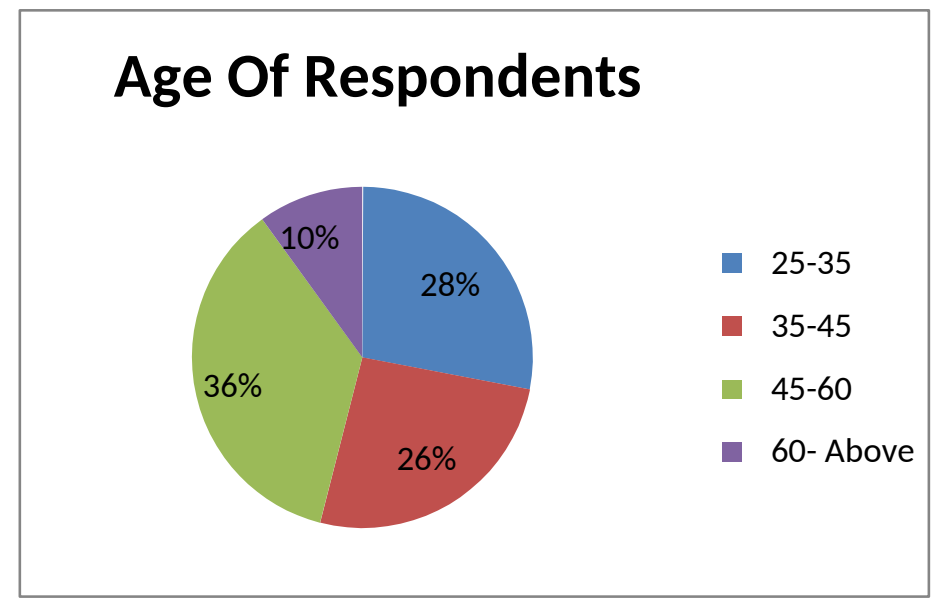




\section{Gender}

\section{Gender Of Respondents}

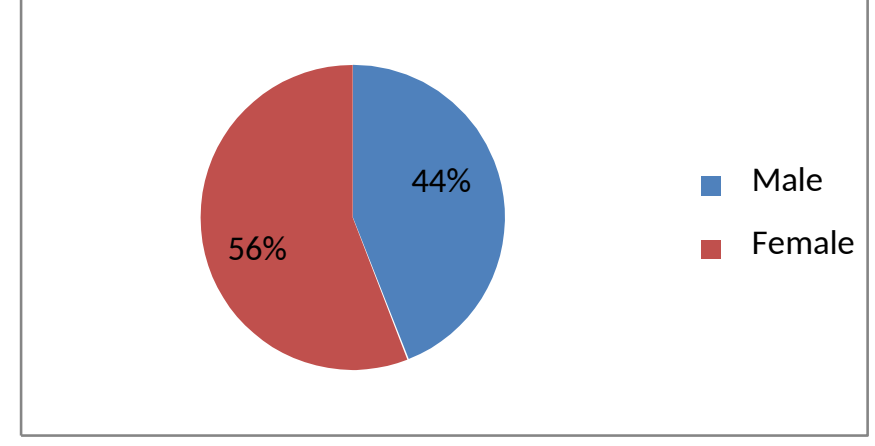

Occupation

\section{Occupation of Respondents}

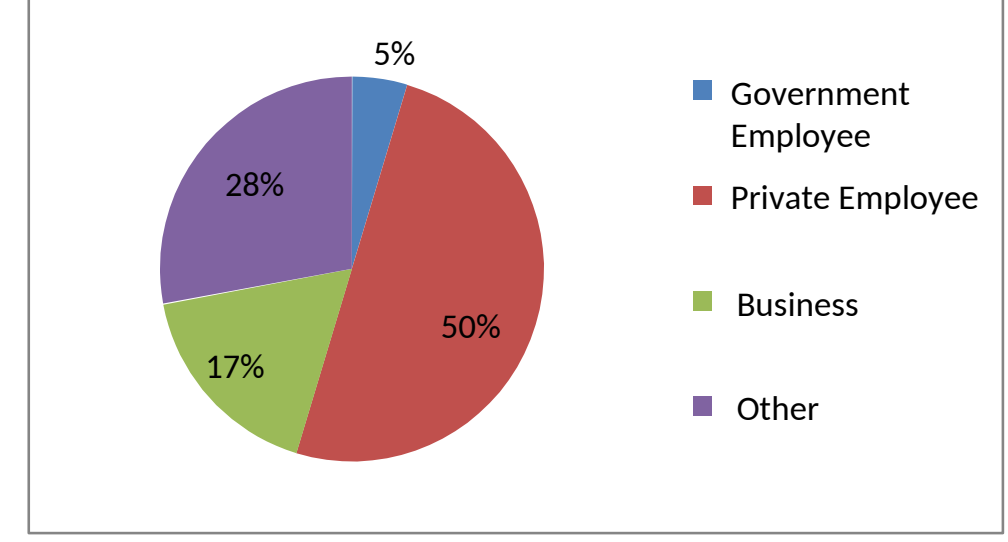


Annual Income (In Rupees)

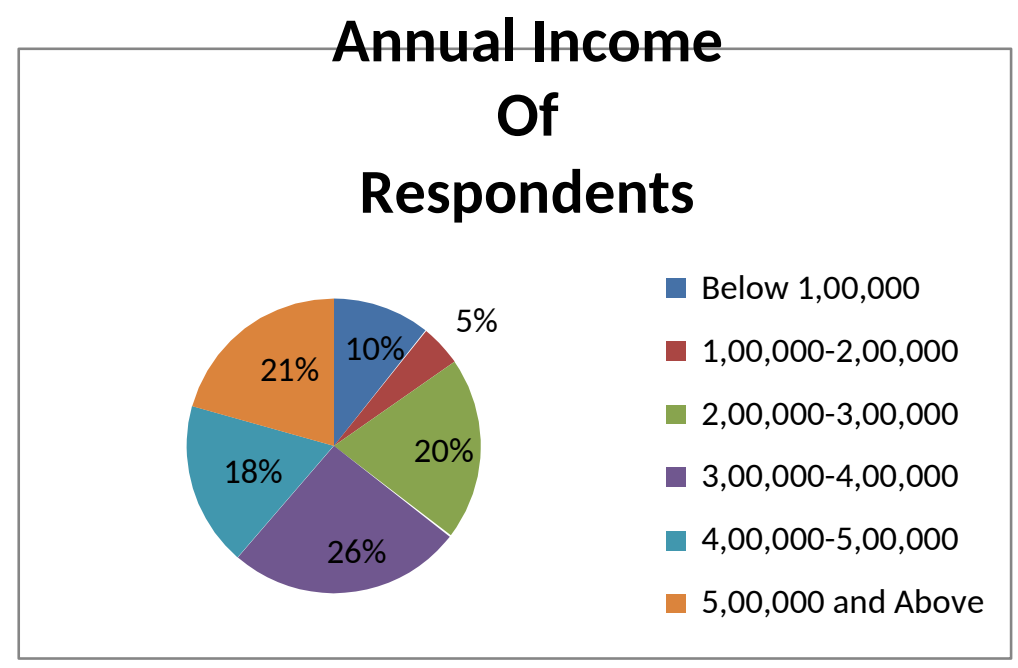

Income Tax Returns

Filing of Income Tax Returns by the Respondents

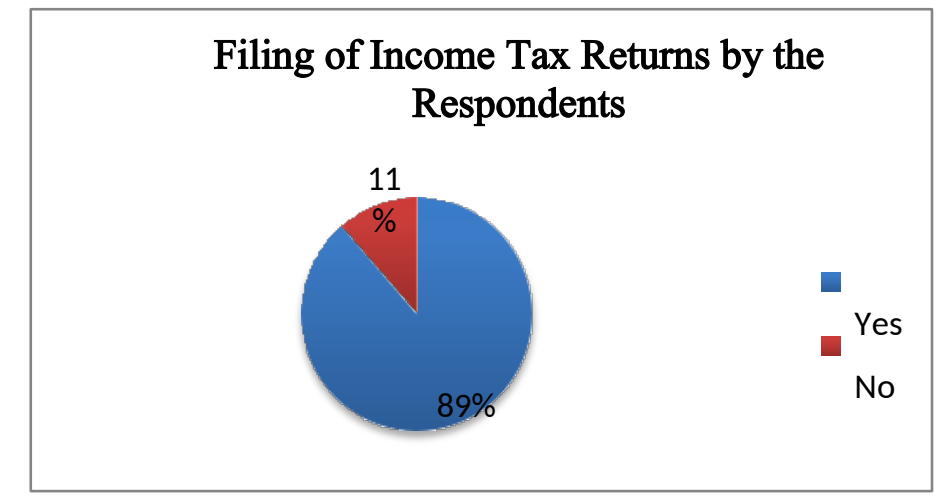

Tax Deductions

Respondents Awareness of Tax Deductions

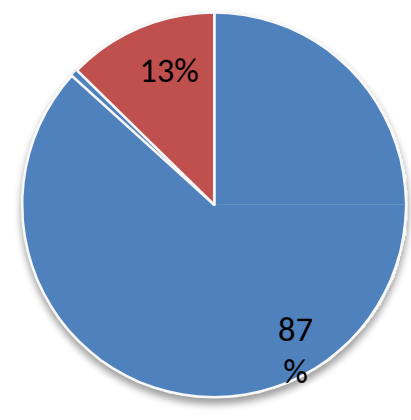


Eligibility of Respondents for Deductions Available from Sec $80 \mathrm{C}$ to $80 \mathrm{U}$

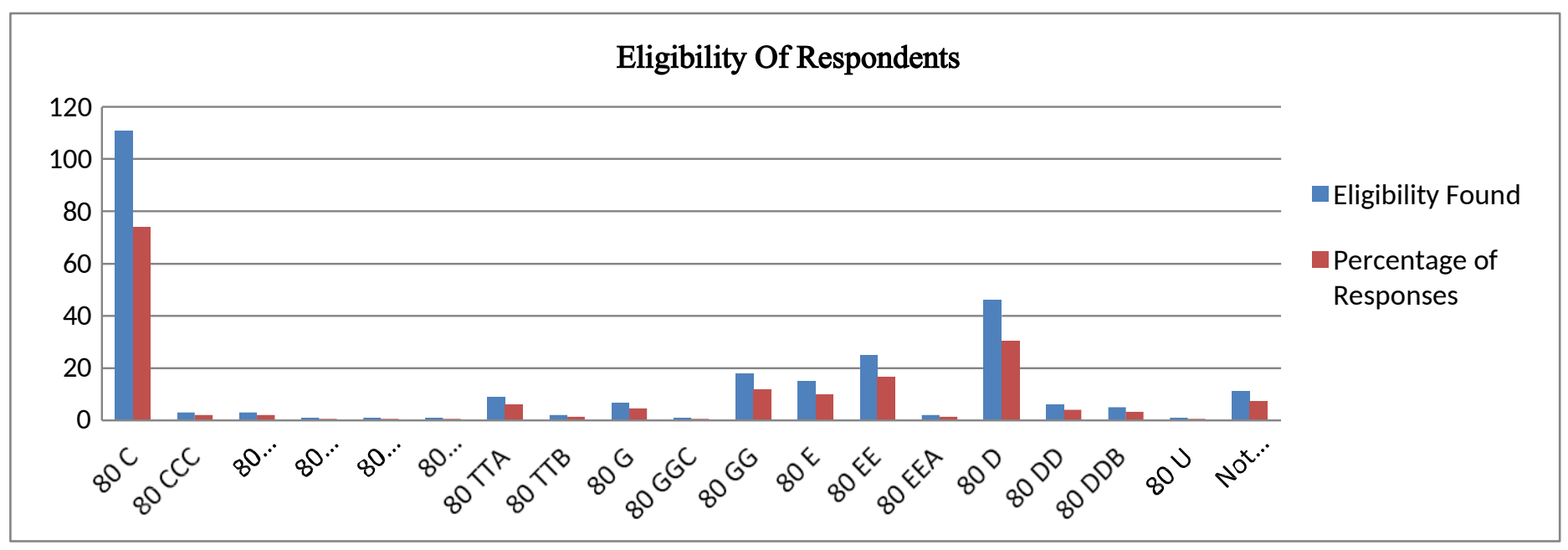

Period of Investment in Tax Saving Products

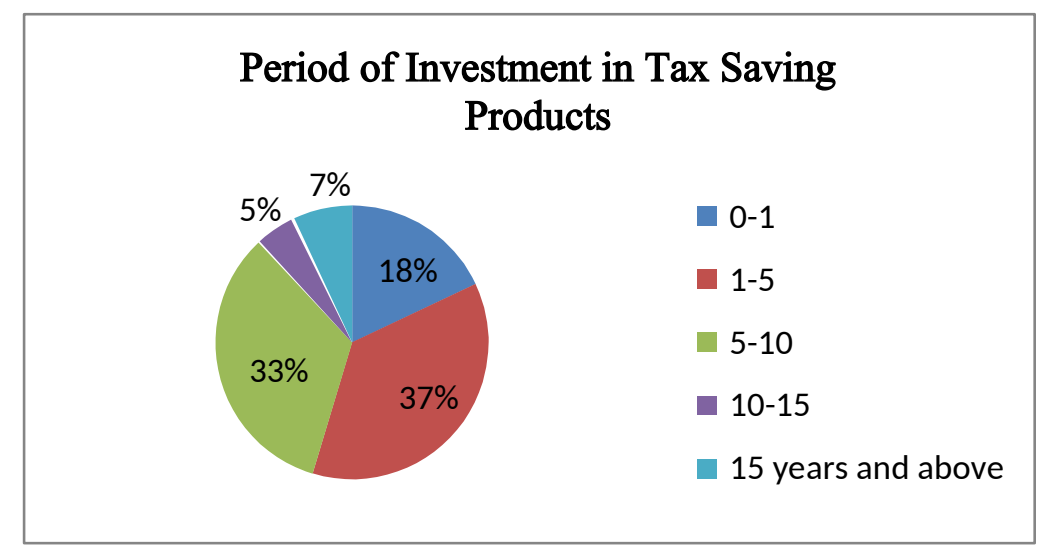

\section{Investment Advice Source}

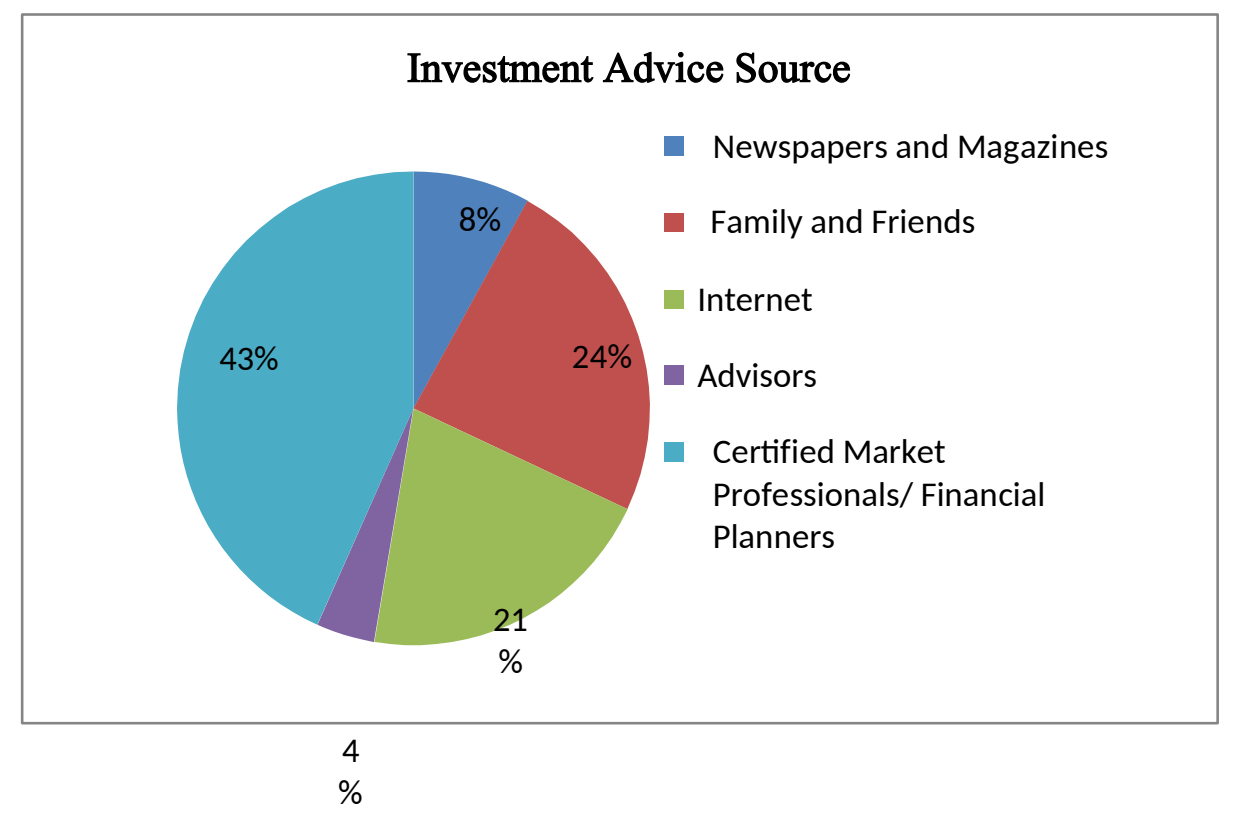




\section{Returns vs Tax Savings}

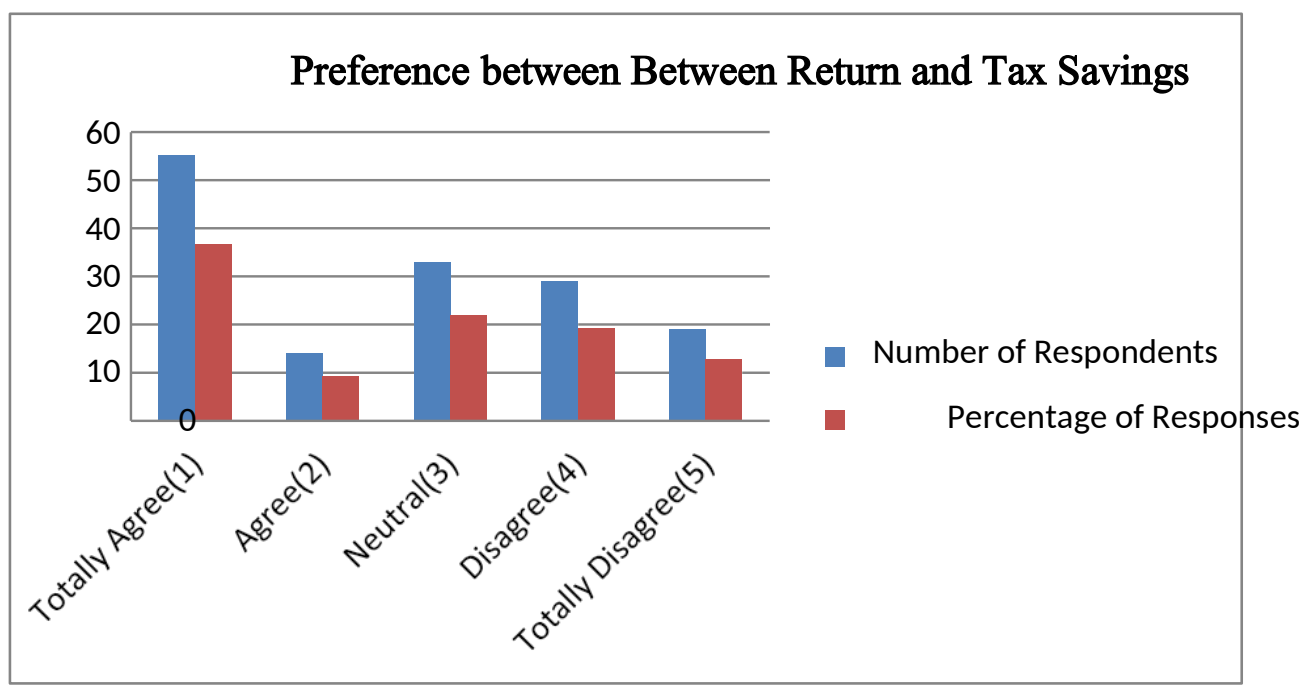

\section{Preference of Investment Options}

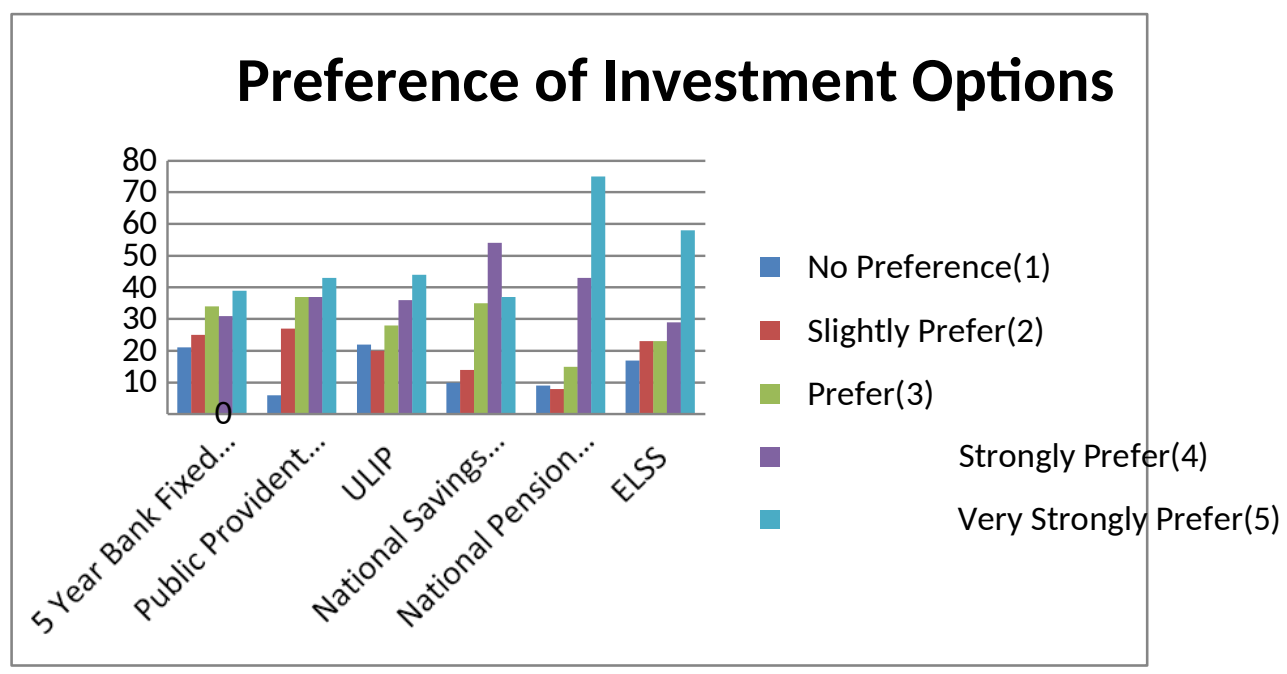

Reason for Selection of Investment Avenue

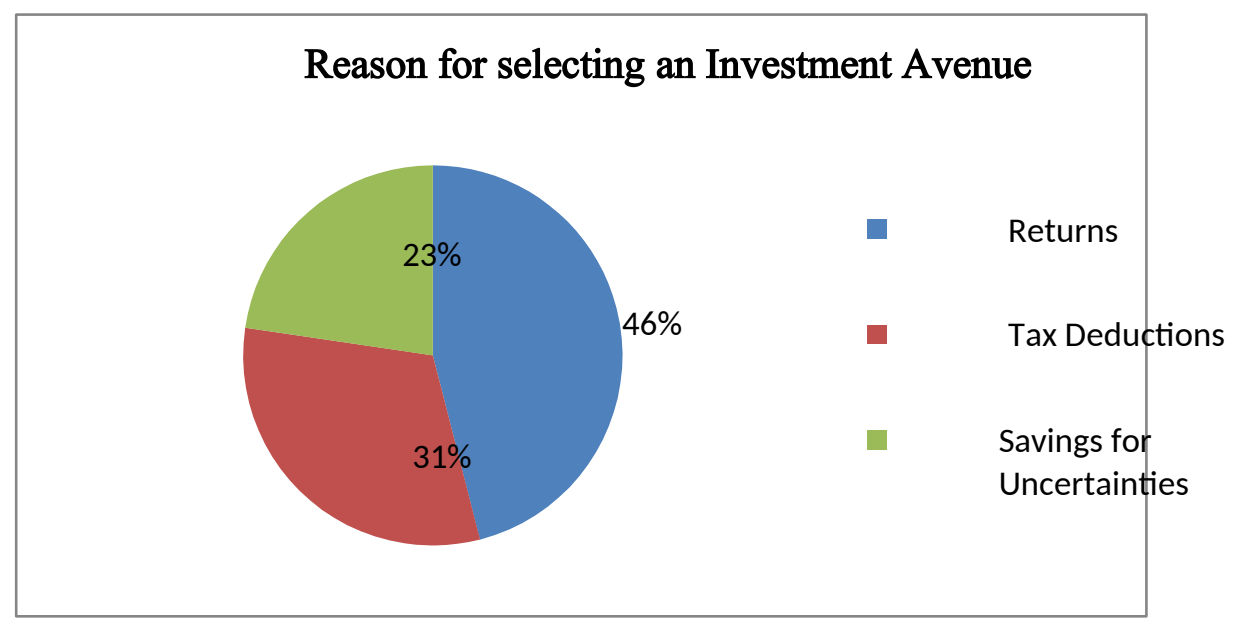




\section{Satisfaction from Investment in Tax Saving Products}

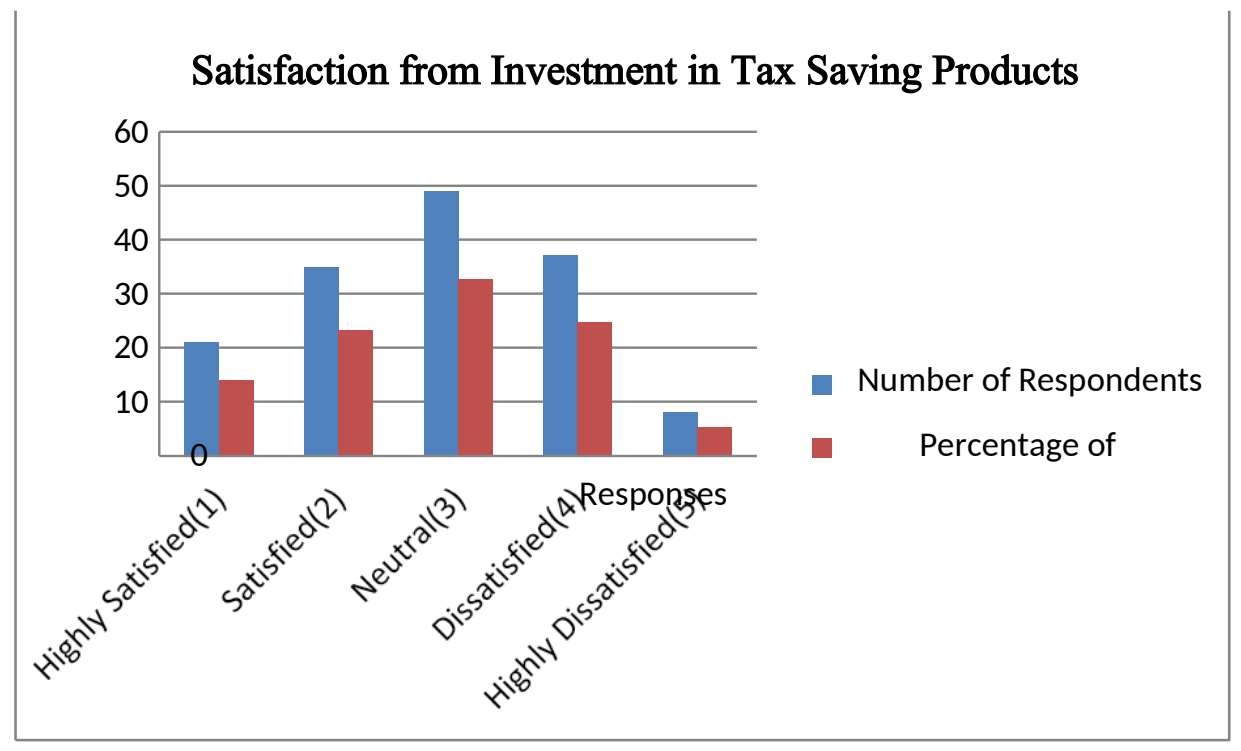

\section{Findings}

- On the basis of the study it has been observed that most of the people prefer investing in National Pension System and have awareness of Tax deductions.

- It has been observed that majority of the respondents were eligible for deductions under Sec $80 \mathrm{C}$ and do tax planning. On the basis of the study it has been observed that people have a neutral response while selecting among returns and Tax Savings and also have neutral satisfaction from the Investment which they make in Tax Savings Products.

- It has been observed that salaried individuals who were the respondents were majorly investing on the basis of the returns that the Investment Avenue generates and depend on Investment Advice given by Certified Market Professionals/ Financial Planners.

\section{Conclusion}

It can be concluded that the respondents have basic knowledge and awareness about various tax saving schemes u/s $80 \mathrm{C}$ only and prefer to invest in National Pension System and National Savings Certificate but are unaware of the various Tax Savings Products that are eligible for deductions and benefits under the remaining sections ranging from Sec $80 \mathrm{CCD}$ to $80 \mathrm{U}$.

\section{References}

1. Dr.Vinod K Singhania, Dr. Monica Singhania, Students' Guide to Income Tax Including GST, Taxmann Publications, 4-1-369-Indralok Commercial Complex Shop No. 15/1 - Ground Floor, Telangana 500001, 356-364.

2. Bindabel and Hamza (2021), 'Relationship between saving and investment pattern and orientation towards finance among working women in the universities of Saudi Arabia', Growing Science, Canada, Vol. no. 7(1), 81-88. Available from

URL:https://www.researchgate.net/publication/344879958.

3. Neha Agarwal (2020), 'A study on tax planning of salaried individual', International Multidisciplinary Conference in, Technology, Business, Management \& Liberal Arts, Vol. no. 9(5), 68-74. Available from URL: https://ijcrt.org/download.php?file=IJCRT2104205.pdf 
4. Arora, A. K., \& Garg, K. (2019), 'Awareness and Perception Regarding Tax Saving Instruments among Teachers of Higher Education'. International Journal of Recent Technology and Engineering, 3, 2277-3878. Available from URL:https://doi.org/10.35940/ijrte.C5847.098319

5. Arora \& Monika (Research Scholar, I. P. T. U. (2019), April Month Milestone. Pacific Business Review International', 136/2017-2(Monthly). URL:http://www.pbr.co.in/2017/april4.aspx

6. Arora, A. K. \& Rathi, P. (2018), 'A Study of Awareness and Perception Regarding Tax Saving Options

7. Among Salaried People', Indian Journal of Finance, 12(7), 57-66. URL: http://www.indianjournaloffinance.co.in/index.php/IJF/article/view/129971

\section{Annexure - 1 Questionnaire:}

A Study on Awareness of Investmentintax Saving Products

1. Name :

2. Age: (a) 25-35 (b) 35-45 (c) 45-55 (d) 55-65 (e) 65 \& Above.

3. Gender: (a) Male (b) Female

4. Occupation: (a) Government Employee (b) Private Employee (c) Business (d) Other.

5. Annual Income(In Rupees):

(a) Below 1,00,000 (b) 1,00,000-2,00,000 (c) 2,00,000-3,00,000 (d) 4,00,000-5,00,000 (e) 5,00,000 \& Above.

6A. Do you file Income Tax Returns? (a) Yes (b) No

6B. Are you aware about the Tax Deductions available from Sec $80(\mathrm{C})$ to $\mathrm{Sec} 80$ (U)? (a) Yes (b) No

6C. Fill in the blank below the Tax Deductions you are eligible for

7. Since how many years have you been investing in Tax Savings Instruments?

(a) 0-1 (b) 1-5 (c) 5-10 (d) 10-15 (e) 15 years and above.

8. Do you prefer Investments having higher returns with low tax deductions or lower returns with higher deductions?

(a) Higher returns with low tax deductions (b) Lower returns with high tax deductions.

9. What is your Investment Advice Source?

(a) Newspapers and Magazines (b) Family and Friends (c) Internet (d) Advisors (e) Certifies Market Professionals/ Financial Planners

10. You are looking for a better return from Investments as compared to Tax Savings.

(a) Totally agree (b) Agree (c) Neutral (d) Disagree (e) Totally Disagree 
11A. From the below rank the investment options you prefer:

\begin{tabular}{|l|c|c|l|l|l|}
\hline Options & $\begin{array}{c}\text { No } \\
\text { Preference }\end{array}$ & $\begin{array}{c}\text { Slightly } \\
\text { Prefer }\end{array}$ & Prefer & $\begin{array}{c}\text { Strongly } \\
\text { Prefer }\end{array}$ & $\begin{array}{c}\text { Very Strongly } \\
\text { Prefer }\end{array}$ \\
\hline 5 Year Bank FD & & & & & \\
\hline PPF & & & & & \\
\hline ULIP & & & & & \\
\hline NSC & & & & & \\
\hline NPS & & & & & \\
\hline ELSS & & & & & \\
\hline
\end{tabular}

11B. And if you prefer investing in above, what is the major reason for you selecting an investment avenue?
(a) Returns
(b) Tax Deductions
(c) Savings for Uncertainties.

11C. And are you satisfied from Investment in Tax Saving Products?

(a) Highly satisfied (b) Satisfied (c) Neutral (d) Dissatisfied (e) Highly dissatisfied. 